\title{
UNA NOTA A EPICTETO I, 23, 6
}

The passage has been diversely commented by Epictetus' editors and translators. The author collects their opinions and offers a new interpretation based on the comparison between this text and Epictetus Discourses II, 4, 6.

Varios son los pasajes de las Disertaciones de Epicteto transmitidas por Arriano dedicados a la crítica de las opiniones de Epicuro y uno de ellos es el que ahora nos ocupa: un capítulo especialmente breve en el que Epicteto intenta refutar los conocidos consejos epicúreos de que el sabio no debe criar hijos ni meterse en política ${ }^{1}$.

Epicteto no recurrirá para ello a elevadas teorías ni complejas argumentaciones, sino que buscará, como suele ${ }^{2}$, ejemplos de la vida diaria con los que poner de manifiesto lo desacertado de las máximas epicúreas en cuestión.

El capítulo empieza poniendo de relieve cómo Epicuro, a pesar de comprender que el hombre es un ser sociable por naturaleza, no puede extenderse sobre ese tema porque ello entraría rápidamente en contradicción con su hipótesis de que «el bien reside en la concha» (Epic., frg. 408) y con el principio general, aceptado tanto por epicúreos como por estoicos, de que «no hay que admirar ni admitir nada alejado de la esencia del bien».

1 Testimonio aportado también por Diógenes Laercio X, 119.

2 Un buen ejemplo de ello lo tenemos è la refutación de los académicos que aparece en III, 20. 
La pregunta retórica «¿Pero cómo se puede sospechar de nosotros que no tengamos un amor natural a los hijos?» da paso a la refutación del primer consejo; Epicteto propone la comparación del ratoncillo ${ }^{3}$ : si no te molesta un ratón que se cría dentro, ni sus grititos, ¿por qué no ibas a soportar a un niño? Es que Epicuro sabe - dice- que una vez que nazca ya no será posible dejar de quererle ni de ocuparse de él.

En relación con el segundo consejo, el de no meterse en política,

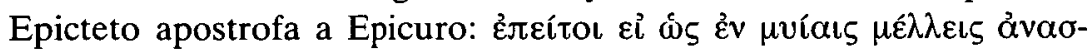

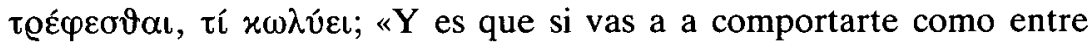
moscas, ¿qué te lo impide?». El pasaje llamó la atención de la mayor parte de los editores ${ }^{4}$ : Wolf, Upton, Schweighäuser, Oldfather y, entre los españoles, Jordán de Urríes ${ }^{5}$, que han ofrecido explicaciones bien diversas.

Para Wolf, se estaría comparando al vulgo con las moscas por lo molestos que pueden ser ambos ${ }^{6}$; Upton se limita a proponer la co-

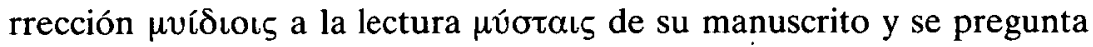
«si no aludirá Epicteto al dicho Ne musca quidem»?.

3 Nos atenemos en nuestra interpretación al texto de los manuscritos, aceptado por la mayor parte de los editores.

4 J. Souilhé no destina comentario alguno al pasaje, aunque sí una nota en el aparato crítico de su edición Epictète. Entretiens. Texte établi et traduit par, vol. I, Paris 1962. La editio maior de Schenkl (Epicteti Dissertationes ad Arriano digestae, Leipzig 1916), que no ofrece comentario, ni siquiera recoge la variante del denominado codex Uptonianus.

5 La edición de Wolf (Basilea, 1560-63, tres vols.) y la de Upton (Londres, 1739-41, dos vols.) me han sido imposibles de consultar directamente, por lo que las referencias que ofrezco de ellas están tomadas de la magnífica edición de J. Schweighauser, Epicteteae Philosophiae Monumenta. Hildesheim-New York 1977 (reprod. fotomecánica de la ed. de Leipzig 1799). vol. I, p. 269. El comentario de W.A. Oldfather aparece recogido en su Epictetus. Tog The Discourses As Reported By Arrian, The Manual And Framents With An English Translation by, vol. I, p. 150. El de P. Jordan de Urries, aparece en Epicteto. Pláticas por Arriano, Barcelona 1957, vol. I, p. 106. Tampoco ha estado a mi alcance la obra de Stellwag, H. F. Het Eerste Boek der Diatriben, Amsterdam 1933.

6 Encuentro la sugerencia de Wolf, basada en el sentido común, parcialmente acertada; cf. la expresión Abige muscas (Cicerón, De oratore II 60) referida a personas molestas según interpreta Kohler, C.S. en su obra Das Tierleben im Sprichwort der Griechen und Romer, (Hildesheim 1967; reprod. fotomec. de la ed. de Leipzig 1881), p. 52. No obstante, la relación entre el texto ciceroniano y el de Epicteto es algo forzada.

7 Suetonio. Vita Domitiani 3: cf. Kohler, o. c. pp. 52-3. 
En la interpretación de Schweighäuser, la comparación residiría en la poca atención que el hombre presta a sus semejantes, tan poca como a las moscas; Oldfather entiende que se refiere a que nada obliga al hombre a comportarse como ser sociable salvo su sentido de lo conveniente; por último, Jordán de Urríes se pregunta si no se tratará de una expresión proverbial.

Parece haber pasado desapercibido a los estudiosos el pasaje II 4, 6, que, a nuestro entender, es determinante para la aclaración del

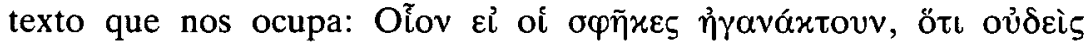

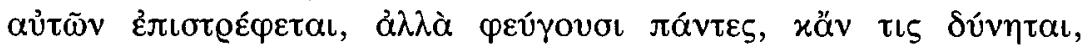
$\pi \lambda \eta ́ \xi \alpha \varsigma$ $\chi \alpha \tau \varepsilon \hat{\beta} \alpha \lambda \varepsilon v$ : “Como si se enfadaran las avispas porque nadie se trata con ellas, sino que todos las rehuyen y, si se puede, se las quita uno de encima a golpes».

Bien es verdad que en un pasaje se habla de moscas y en otro de avispas, pero en la Grecia Antigua tanto las unas como las otras eran insectos poco apreciados: si las avispas tenían como características más destacadas la viveza e imprevisibilidad de su temperamento y, sobre todo, la irritabilidad ${ }^{8}$, a las moscas se les atribuían la osadía, la persistencia y la desvergüenza ${ }^{9}$.

Puesto que ambos insectos tienen en común el no poseer ninguna cualidad beneficiosa para los humanos y - aunque no llegan a ser considerados propiamente «malignos», como el escorpión - no son nunca bien recibidos, parece razonable que la respuesta humana a la presencia de moscas o de avispas sea del mismo carácter: quitárselas uno de encima a golpes, según se indica en II 4, 6 .

La interpretación que aquí proponemos tendría a su favor, frente a las mencionadas anteriormente, el apoyo ofrecido por la referencia textual. Desde nuestro punto de vista, la refutación de Epicuro resulta ahora no exenta de cierta malevolencia: al usar esa comparación tan despectiva, Epicteto parece atribuir a los epicúreos un sentimiento de desprecio hostil hacia el género humano.

Paloma Ortiz García

8 Cf. Davies, M. y Kathirithamby J., Greek Insects, Londres 1986, pp. 75-76; Beavis, I.C., Insects and Other Invertebrates in Classical Antiquity, Oxford 1988, p. 193.

9 Davies y Kathirithamby, o. c. p. 155, Beavis, o. c., pp. 222-3. 